\title{
Judikatura Evropského soudu pro lidská práva v praxi Nejvyššího správního soudu
}

\section{The Case Law of the European Court of Human Rights and the Practice of the Supreme Administrative Court}

\author{
Zdeněk Kühn ${ }^{*}$
}

\begin{abstract}
Abstrakt
Tento text se zaméruje na kapitolu kniby Domestic Judicial Treatment of European Court of Human Rights Case Law: Beyond Compliance (KOSAŘ, D. et al. Routledge, 2020) věnovanou poư̌ivání judikatury Evropského soudu pro lidská práva Nejyyššrim správním soudem. Clánek poukazuje na dalši důležité aspekty, k.teré ovlivnuiu použiváni judikatury ESLP českými vrcholnými soudy. Tyto aspekty vyniknou zejména pri srovnáni se situaci v Mad’arsku a Polsku. Clánek dále kriticky komentuje judikaturu Ústavního soudu pri posuzováni souladu zákona a mezinárodni lidskoprávni normy. Konečnè, autor nabizi své situované úvaby soudce Nejvyšsího správního soudu k prípadům, kdy se vnitrostátní soud vymezi proti rozsudku Evropského soudu pro lidská práva.
\end{abstract}

Klíčová slova

Evropský soud pro lidská práva; Evropská úmluva pro lidská práva; Nejvyšš́ správní soud; Ústavní soud; compliance; ne bis in idem; justicni revolty.

\begin{abstract}
This article focuses on judicial treatment of the European Court of Human Rights case law by the Supreme Administrative Court, as analysed in the book. Domestic Judicial Treatment of the European Court of Human Rights Case Law: Beyond Compliance (KOSAŘ, D. et al. Routledge, 2020). The article discusses additional important elements that influence the use of ECtHR case law by Czech apex courts. These additional elements shed light on the Czech practice, especially when compared to the situation in Hungary and Poland. The article also critically comments on the Czech Constitutional Court judgment concerning the assessment of a domestic law's conformity with an international buman rights treaty. Finally, the author presents his situated contemplations of a judge of the Czech Supreme Administrative Court on cases where a national court revolts against a European Court of Human Rights judgment.
\end{abstract}

\section{Keywords}

The European Court of Human Rights; the European Convention on Human Rights; the Czech Supreme Administrative Court; the Caech Constitutional Court; Compliance; ne bis in idem; Judicial Revolts.

\footnotetext{
Prof. JUDr. Zdeněk Kühn, Ph.D., LL.M., S. J. D., Právnická fakulta, Univerzita Karlova, Praha; Nejvyšší správní soud, Brno / Faculty of Law, Charles University, Prague, Czech Republic; Supreme Administrative Court, Brno, Czech Republic / E-mail: kuhnz@prf.cuni.cz / ORCID: 0000-0001-6952-3561 / Research ID: 8710518100
} 


\section{Poznámka prvá: důvody otevřenosti správního soudnictví vưči lidskoprávním argumentům ze Štrasburku netřeba hledat jen v instituci Nejvyššího správního soudu}

Česká správní justice je dnes popisována hlavně institucí Nejvyššího správního soudu (NSS), který soustavu správního soudnictví zaštit’uje jako „druhá hlava draka české justiční soustavy“ (příměr „dvouhlavé saně“ v roce 2002 asi poprvé použil jeden ze spolutvůrců nového správního soudnictví Michal Mazanec při projednávání návrhu nového soudního řádu správního). Činí tak i Jan Petrov, autor kapitoly o používání judikatury ESLP v praxi NSS.

Skutečnost, že judikatura ESLP je v praxi NSS poměrně často aplikována, a to ve větším počtu, než by se dalo s ohledem na zaměření českého správního soudnictví čekat, vysvětluje Petrov tím, že NSS je novým soudem, založeným v roce 2003 v podstatě na zelené louce. Jeho personální složení je pestré, zcela jistě mnohem pestřejší než složení Nejvyššího soudu, který se skládá z převážně kariérních a vnitřně specializovaných soudců.

S tímto vysvětlením, proč je judikatura NSS otevřená vlivům (nejen) judikatury ESLP, ale třebas i srovnávacího práva a srovnávací právní argumentace, lze jistě souhlasit. Ostatně sám jsem jedním z těch, o nichž Petrov hovoří, a mé obzory opravdu sahají poněkud dále než k Aši na západní hranici našeho státu. Není dobré zapomínat ani na velmi kvalitní asistenty, kteří mohou se stylem soudního odůvodnění v dobrém i zlém také hodně udělat. Kvalitní a prestižní soud přitahuje kvalitní personál.

Ovšem myslím si, že je tu ještě jeden důležitý důvod otevřenosti správního soudnictví. Tento důvod přesahuje datum ustavení NSS v roce 2003 a sahá až do 90. let minulého století, do doby zrození novodobé české správní justice, byt’ tehdy vlastně jen v provizorní podobě. Česká správní justice, tehdy ještě nezaštítěná vrcholným soudním orgánem sjednocujícím správní judikaturu, existovala v letech 1992 až 2002 a již v této době můžeme pozorovat pozoruhodné deviace soudního a citačního stylu ve srovnání se zbytkem českého soudnictví. Když jsme před více než deseti lety psali s mým polským a mad’arským kolegou srovnávací kvantitativní analýzu, ve které jsme zjiššovali argumentační a citační mody správní justice ve střední Evropě, zaměřili jsme se na etapu konce první postkomunistické dekády až do roku 2004, roku, ve kterém Polsko, Mad’arsko a Česko vstoupily do EU (1999-2004). Polské a mad’arské výsledky byly podobné a ukazovaly na to, že tamní správní soudy se zaměřují jen na „vnitřní standardy“ výkladu domácího práva (metoda jazyková, „logická“, systematická, případně domácí judikatura). Naproti tomu české správní soudy již v oněch šesti letech na přelomu století vykazovaly mnohem vyššî míru otevřenosti nejen standardům právu externím (zejm. komplex argumentů teleologických), ale též argumentům ústavněprávní povahy včetně odkazů na judikaturu ESLP. ${ }^{1}$

1 MATCZAK, Marcin, Matyas BENCZE a Zdeněk KÜHN. Constitutions, EU law and judicial strategies in the Czech Republic, Hungary and Poland. Journal of Public Policy, 2010, č. 1, sv. 30, s. 81-99. 
Výsledky z českého právního systému poněkud narušily monolitní představu postkomunistické právní kultury ve střední Evropě, kterou jsme tehdy s kolegy měli. Musel jsem proto v oné práci vysvětlit, proč byl český správní soudce mnohem vstřícnější vůči judikatuře ESLP a obecně vưči argumentům supranacionální povahy ještě před vznikem „progresivního“ NSS. Podle mne klíčovým rozdílem mezi Českem na straně jedné a Polskem a Mad’arskem na straně druhé v té době bylo, že jen v českém právním řádu existovala plnohodnotná ústavní stížnost proti soudnímu rozhodnutí. V Polsku neexistuje dodnes (stěžovatelé mohou napadat jen protiústavnost zákona, nikoliv aktu jeho aplikace), v Mad'arsku až od roku 2011 (přijetí nové mad'arské ústavy), třebas na Slovensku se objevila až od roku 2002. Na rozdíl od Polska a Mad’arska byli čeští správní soudci v dennodenním kontaktu s rezolutně antiformalistickým Ústavním soudem. Během prvních deseti let své existence (1993-2003) český Ústavní soud opakovaně zdůrazňoval antiformalistické aspekty soudcovské interpretace a kritizoval excesivní zákonný pozitivismus a textualismus obecné justice. ${ }^{2}$ Soudci Ústavního soudu i v pracích doktrinálních zdůrazňovali, že pohyb směrem k teleologické argumentaci musí být realizován nejen v judikatuře, ale též v právní doktríně. ${ }^{3}$ Český správní soudce, který se potýkal s judikaturou Ústavního soudu, byl v podstatě nucen vykročit z omezeného pole zákonného pozitivismu a vázané ideologie aplikace práva a hledat též jiné zdroje pro svou argumentaci. Právě proto nezrrídka vykročil z českých luhů a hájů a hledal inspiraci též v judikatuře štrasburské. Ta mu totiž mohla zaručit, že jeho rozhodnutí nebude v eventuálním řízení o ústavní stížnosti rušeno.

Čím byla správní justice 90. let (až do roku 2002) specifická, byla též př́má interakce mezi správními soudy a ústavním tribunálem. Zatímco ústavní stížnost proti rozhodnutím civilním a trestním bylo možno podat až po vyčerpání všech v úvahu připadajících instancí, ve správní justici byla instance jediná, roztroušená mezi krajské soudy. Neexistoval až do roku 2003 žádný soud, který by často dramaticky odlišnou „krajskou“ judikaturu sjednocoval. Jedinou cestou, která se tehdy nabízela, byla ústavní stížnost, a Ústavní soud nezř́idka suploval právě chybějící nejvyšší instanci správního soudnictví. Mou tezí tedy je, že právě chybějící NSS v 90. letech přispěl k tomu, že si správní soudci mnohem dříve než jejich civilní a trestní kolegové uvědomili význam ústavněprávní a mezinárodní argumentace. Protiústavní nečinnost zákonodárce, který teprve po deseti letech od přijetí ústavy nakonec do našeho práva zakotvil NSS, tak vlastně pomohla rychlejší mentální transformaci správního soudnictví. Nezapomeňme ostatně na to, že první soudci, kteří v roce 2003 na NSS přicházeli, byli právě soudci tehdejších správních úseků.

2 Detailně jsem se pokusil význam Ústavního soudu pro metodologickou transformaci obecné justice (aniž bych nějak zvlášt' hovořil o justici správnî) v práci KÜHN, Zdeněk. Význam proměny soudcovské ideologie aplikace práva ve světle ústavní judikatury let 1993-2003. Právní roz̧bledy, 2004, č. 4, sv. 12, s. 123-129.

3 HOLLÄNDER, Pavel, Ústavnępráuni argumentace. Oblédnutí po deseti letech Ústavního soudu. Praha: Linde, 2003. 
Naproti tomu mad’arský ústavní soud, vybavený až do roku 2011 pouze pravomocemi abstraktního přezkumu ústavnosti, neuspěl ve svých pokusech o transformaci obecné justice. Tak mohl mad'arský autor ještě v roce 2002 napsat, že „stále ještě lže rúci, že vètšina obecných soudcu nevidi žádný vątah mezi ústavou a jejich běžnou rozhodovací činnosti" ". Polský Ústavní tribunál rovněž přiliš neovlivnil rozhodovací praxi obecných soudů, jak naznačují studie z konce druhé postkomunistické dekády. ${ }^{5}$

Právě tím byly české správní soudy unikátní též v perspektivě středoevropské. A právě proto není třeba hledat příčiny větší otevřenosti správní justice jen v personálním složení NSS. V roce 2003, kdy tento soud vznikl, již existovalo podhoubí pro větší otevřenost právní argumentace, podhoubí, které bylo ze shora uvedených důvodů slabší v obecné justici.

\section{Poznámka druhá: jak „prvý“ Ústavní soud ve svém lidskoprávním aktivismu při- pravil možnou cestu pro budoucí autoritářskou exekutivu a její ovládnutí justice}

Na s. 149 Petrov zmiňuje možnost obecného soudu neaplikovat zákon pro jeho rozpor s Úmluvou. Současně upozorňuje na judikaturu Ústavního soudu (Pl. ÚS 36/01), která novelizovaný článek 10 Ústavy „přepsala“ a dále si nárokuje monopol na vyslovení nesouladu zákona a mezinárodní lidskoprávní smlouvy, včetně Úmluvy. Konečně ukazuje ojedinělé př́klady „revolty“ uvnitř NSS, kdy rozhodující senát prohlásil zákon neaplikovatelný pro jeho rozpor s Úmluvou. ${ }^{6}$

Myslím, že by stálo za to tuto relativně stručnou zmínku trochu rozvést. Nový čl. 10 Ústavy v roce 2001 opustil v mezinárodním srovnání zcela ojedinělou kategorii mezinárodních smluv o lidských právech a základních svobodách a nahradil ji inkorporací všech mezinárodních smluv ratifikovaných se souhlasem Parlamentu. Úpravou čl. 10 Ústavy a zakotvením aplikační přednosti ratifikovaných mezinárodních smluv český ústavodárce jednoznačně odmítl tezi, že kontrola souladu zákonů s (nejen lidskoprávními) mezinárodními smlouvami je výlučnou doménou Ústavního soudu. Tomu odpovídá model opakovaného neaplikování zákona, vedoucí k jeho obsoletnosti, namísto formální derogace. Prakticky nemusí být žádný dramatický rozdíl mezi formální derogací zákona Ústavním soudem a jeho opakovanou neaplikací obecnými soudy.

4 HALMAI, Gábor. The Hungarian Approach to Constitutional Review: The End of Activism? The First Decade of the Hungarian Constitutional Court. In: SADURSKI, Wojciech (ed.). Constitutional Justice, East and West. Democratic Legitimacy and Constitutional Courts in Post-Communist Europe in a Comparative Perspective, 2002, s. 189 a násl., s. 209.

5 STAWECKI, Tomasz et al. Between Polycentrism and Fragmentation. The Impact of Constitutional Tribunal Rulings on the Polish Legal Order. Ernst \& Young Better Government Programme Report, Warsaw, 2008.

6 Rozsudek NSS ze dne 11. 7. 2007, čj. 6 As 55/2006-96, č. 1351/2007 Sb. NSS, který se proti nálezu Pl. ÚS 36/01 prrímo vymezil a zdůraznil, že NSS musí poslechnout jasného a prrímého prríkazu čl. 10 Ústavy.

7 Srov. pro ranou reflexi euronovely Ústavy KYSELA, Jan a Zdeněk KÜHN. Aplikace mezinárodního práva po príijetí tzv. Euronovely Ústavy ČR. Právní roæ̋bledy, 2002, č. 7, sv. 10, s. 301 a násl. 
Nicméně krátce po přijetí euronovely Ústavy (č. 395/2001 Sb.) Ústavní soud nálezem Pl. ÚS 36/01 na sebe atrahoval výlučnou derogační pravomoc vnitrostátních předpisů ve vztahu k mezinárodním smlouvám o lidských právech a základních svobodách (které přitom od 1. 6. 2002 platná Ústava staví naroveň ostatním mezinárodním smlouvám a jako nějakou samostatnou ústavněprávní kategorii je ani nezná). Podle Ústavního soudu čl. 112 odst. 1 Ústavy údajně nevymezuje ústavní pořádek taxativně, „nýbrž je i vzhledem k čl. 1 odst. 2 Ústavy“ nutno tam zahrnout i „ratifikované a vyhlášené mezinárodní smlouvy o lidských právech a základních svobodách.“ Jak Ústavní soud vysvětlil, „[ú]stavni zakotveni v šeobecné inkorporačni normy, a tím prekeonáni dualistické koncepce vžtahu práva mezinárodního a práva vnitrostátního, nelze interpretovat ve smyslu odstranéní referenčního bledisk a ratifikovaných a vyhlášených mezinárodních smluv o lidských právech a základních svobodách pro posurováni vnitrostátního práva Ústavním soudem, a to s derogačnimi duisledky. "Proto je i nyní „povinností obecnébo soudu prèdložit Ústavnimu soudu k posouzeni rovněž věc, v níž dojde k závèru, že zákon, jehož má být pri jejim rěseni použito, je v rozporu s ratifikovanou a vyblášenou mezinárodni smlouvou o lidských právech a zákeladnich svobodách."8

Jakkoliv byl nález Pl. ÚS 36/01 svého času notně kritizován, ${ }^{9}$ s odstupem času lze říci, že Ústavní soud tuto kritiku nikdy neakceptoval. Naopak, nález Pl. ÚS 36/01 se stal za téměř dvacet let pevnou součástí jeho ustálené judikatury. ${ }^{10}$

Petrov cituje rozsudek NSS č. 1351/2007 Sb. NSS, který proti judikatuře Ústavního soudu otevřeně revoltoval. V roce 2007 jsem ještě nebyl soudcem NSS, ovšem z mé literární činnosti je vidět, že považuji názor Ústavního soudu ve věci Pl. ÚS 36/01 za omyl. Ovšem omyl, který je součástí ustálené judikatury. Totální centralizace přezkumu ústavnosti zákonů (včetně přezkumu jejich souladu s lidskoprávními mezinárodními smlouvami) však může - v rozporu s tím, k čemu směřoval Ústavní soud v nálezu Pl. ÚS 36/01 ve skutečnosti právní stát a ochranu práv oslabit. Jak se totiž ukazuje v posledním vývoji v Polsku a Mad’arsku, pro novodobé autoritáře je poměrně snadné ovládnout ústavní soud. ${ }^{11}$ Je to v každém př́ípadě mnohem snadnější než ovládnout celou obecnou justici.

8 Nález ze dne 25. 6. 2002, sp. zn. Pl. ÚS 36/01 (N 80/26 SbNU 317; 403/2002 Sb.) - Konkursni nález:

9 FILIP, Jan. Nález č. 403/2002 Sb. jako rukavice hozená ústavodárci Ústavním soudem. In: Právní zpravodaj, 2002, č. 11 a zmínky v jeho četných dalších pracích; KÜHN, Zdeněk a Jan KYSELA. Je Ústavou vždy to, co Ústavní soud řekne, že Ústava je? Casopis pro právni védu a praxi, 2002, č. 3, s. 199-214; KÜHN, Zdeněk. O konci jednoho právního paradigmatu, třech středoevropských ústavních režimech a perspektivě aplikace komunitárního práva. In: KYSELA, Jan (uspoř.). Deset let Ústavy České republiky: východiska, stav, perspektivy, Praha, 2003, s. 195 a násl. Srov. z pozdějších prací zejména MLSNA, Petr a Jan KNĚŽÍNEK. Mezinárodni smlouvy v českém právu. Praha: Linde, 2009.

10 Nález Pl. ÚS 36/01 byl výslovně potvrzen např. nálezem ze dne 24. 6. 2003, sp. zn. Pl. ÚS 44/02 (N 98/30 SbNU 417; 210/2003 Sb.) - Právo konkurzního véritele podat odvolání proti usnesení o zamítnutí konkuræu pro nedostatek majetku. V nálezu Pl. ÚS 44/02 navíc Ústavní soud použil extenzivní výklad ústavního pořádku (zahrnujícího též lidskoprávní mezinárodní smlouvy) přímo jako součást rozhodovacích důvodi̊, nikoliv jen jako obiter dictum, jak tomu bylo v nálezu Pl. ÚS 36/01.

11 Srov. k tomu KÜHN, Zdeněk. Soudy v autoritativním státě. Právník, 2019, č. 11, sv. 158, s. 981-996. 
Tím, že si český Ústavní soud monopolizoval přezkum shody zákonů též s lidskoprávními smlouvami, tak paradoxně možnosti obrany demokracie do budoucna oslabil.

Není však třeba, aby obecné soudy nález Pl. ÚS 36/01 př́mo nerespektovaly či proti němu revoltovaly. Mnohem rozumnější je přímá aplikace mezinárodní smlouvy, tedy „dovysvětleni'“ zákona v rovině interpretační. V případě mnoha konfliktů mezi mezinárodní smlouvou a zákonem totiž není řešením derogace zákona $\mathrm{v}$ řízení před Ústavním soudem podle čl. 95 odst. 2 Ústavy. Zákonné ustanovení bude často obecně ústavně bezproblémové a v obecné rovině souladné též s mezinárodní smlouvou. Př́íkladem bude situace, kdy mezinárodní smlouva stanoví určitou výjimku k zákonem obecně stanovené (bezvýjimečné) normě, anebo přidá nějakou další výjimku k zákonem (taxativně vypočteným) výjimkám. $\mathrm{V}$ takovém prrípadě derogace zákona není namístě, namístě je bud' jeho interpretace souladná s mezinárodní smlouvou (nap̌r. vyplnění zákonného demonstrativního výčtu výjimek též o výjimku mající základ v mezinárodní smlouvě), anebo přímá aplikace mezinárodní smlouvy a doplnění na prvý pohled bezvýjimečného textu zákona o výjimku založenou v mezinárodní smlouvě.

\section{Poznámka třetí: př́iběh „vzpoury“ NSS proti ESLP ve věci Zolotukhin a malé zamyšlení se $\mathrm{k}$ justičním revoltám obecně}

Petrov věnuje zaslouženě velkou pozornost případu, kde se NSS vymezil proti judikatuře ESLP (s. 154-156). Dovolím si k tomuto tématu přičinit pár poznámek, nebot’ jsem byl v roce 2012 členem rozhodujícího senátu.

Analyzovanou problematiku odstartoval rozsudek velkého senátu ESLP Zolotukhin proti Rusku. ${ }^{12} \mathrm{~V}$ tomto rozsudku ESLP sjednotil do té doby rozporný př́stup k problematice zákazu dvojího postihu za tentýž čin tak, že otázka stejného činu (skutku) se má hodnotit de facto, nikoliv de iure (se zřetelem na právem chráněné hodnoty). Stanovení, zda se jedná o tytéž trestné činy (idem), závisí dle ESLP na skutkovém posouzení (Ibid., \84), nikoli např́iklad na formálním posouzení založeném na porovnání „základních znakư“ dotčených trestných činů. Zákaz se týká stíhání nebo řízení ve vztahu ke druhému „trestnému činu“", pokud se tento zakládá na týchž skutkových okolnostech či skutečnostech, které jsou v podstatě stejné. Klíčovým okamžikem, kdy se aktivuje čl. 4 Protokolu č. 7, je zahájení nového (druhého) trestního stíhání v případě, kdy předchozí osvobozující či odsuzující rozsudek nabyl právní moci. Popisy skutkového stavu v obou řízeních představují vhodný odrazový můstek pro posouzení otázky, zda jsou skutky v obou řízeních totožné (resp. jsou totožné alespoň v podstatných rysech), a to bez ohledu na prípadné odlišnosti v právní kvalifikaci tohoto skutku v obou řízeních (\83). Totožnost skutku je dána tehdy, pokud se konkrétní skutkové okolnosti týkají téhož obžalovaného a jsou neoddělitelně spjaty v čase a místě (\84).

12 Rozsudek velkého senátu ESLP ze dne 10. 2. 2009, Sergey Zolotukbin proti Rusku, č. 14939/03. 
Z judikatury ESLP tedy jasně plyne, že pro určení totožnosti skutku je rozhodující skutek jako takový, fakta skutku (tedy skutek de facto, idem factum), nikoliv jeho právní kvalifikace, prrípadně odlišné právem chráněné hodnoty (skutek de iure). ESLP to posléze shrnul jako „totéž jednáni týchž osob v tentýž čas “13 Skutek je v tomto chápání rozlišován jím samým, fakta utvářející skutek jsou chápána jako objektivní, sama o sobě stojící kategorie.

Kritici tohoto pojetí však upozorňují na filozofickou i praktickou neudržitelnost těchto premis. V podstatě celá moderní filosofie dovozuje, že proces poznání nelze pojímat jako pouhou fyzicko-empirickou př́čcinnou souvislost. Veškerá zkušenost předpokládá apriorní formy (pojmy, zásady, ideje), které nepocházejí ze zkušenosti. ${ }^{14}$ Fakta tedy nikdy neexistují sama o sobě. Jistá fakta sice aktivují použití určité právní kvalifikace, avšak teprve daná právní kvalifikace činí některá fakta relevantní a jiná irelevantní. Z tohoto důvodu skutkový základ konkrétní kauzy není nikdy zcela oddělitelný od norem, které jej regulují. Nemá-li být proces vymezení konkrétního skutku zcela arbitrární, pak je při rozhodování o tom, které z nepřeberného množství rozličných skutkových okolností budou k danému skutku vztaženy, vždy nutno určitým způsobem zohlednit právní kvalifikaci dotčeného deliktu. ${ }^{15}$

Právě podané dilema není pouhá prázdná filozofická disputace. V praxi správního trestání totiž faktické (de facto) pojetí skutku vyvolává dlouhodobé problémy. ${ }^{16}$ Těmi jsou jednak otázky kolem dvojîho trestání za rưzné správní delikty upravené různými zákony chránícími různé hodnoty, jednak specifická situace souběžného trestního stíhání za daňové trestné činy a ukládání daňového penále daňovou správou. Jakkoliv je v poslední době českou právnickou debatou akcentována spíše otázka druhá, tvrdím, že reálně představuje ještě větší problém situace prvá, tedy problematika souběžného správního trestání různými správními orgány za různé správní delikty mající původ ve stejném skutku.

Ve správním právu je častá situace, že totéž jednání naplňuje skutkové znaky různých správních deliktů v různých sektorových zákonech, a to v závislosti na odlišných následcích jednání a odlišných právem chráněných hodnotách. Jinými slovy, ve správním právu se neustále střetáváme s vymezením skutku de facto a de iure. Př́kladem je právě situace řešená rozsudkem NSS ve věci kasační stížnosti obce Kralice nad Oslavou. ${ }^{17} \mathrm{~V}$ daném

13 Rozsudek ESLP ze dne 25. 6. 2009, Maresti proti Chorvatsku, č. 55759/07, 』 63.

14 Srov. ANZENBACHER, Arno. Úvod do filosofie. Praha: Portál, 2004, s. 101-132.

15 Podobné úvahy se objevují též v rozsudku NSS ze dne 11. 1. 2012, čj. 1 As 125/2011-163, bod 33. Jde o rozsudek, který se vzepřel právě judikátu Zolotukhin.

16 Pro početný sumář judikatury k tomuto tématu srov. BURDA, Zdeněk. Nad judikaturou v oblasti dvojího trestání za jedno provinění. Daně a právo v praxi, 30. 6. 2017, s. 47.

17 Cit. rozsudek NSS čj. 1 As 125/2011-163, obec Kralice nad Oslavou. Kriticky k judikatuře ESLP srov. též ZUPANČIČ, Boštjan. Ne bis in idem (zabrana ponovnog suđenja za isto delo). La belle dame sans merci. Crimen, 2012, č. 2, s. 172-173. Právě Zupančič, tehdejší soudce ESLP za Slovinsko, byl shodou okolností na podzim 2011 hostem NSS a měl na soudě sérii přednášek. Právě jeho názory i prezentované publikace ovlivnily finální podobu rozsudku v kauze Kralice. 
př́padě se zdálo, že ve smyslu rozhodnutí Zolotukhin byla obec potrestána třikrát za stejný skutek. Jakkoliv se všech tř́ deliktů obec dopustila v podstatě jedním jednáním, v sázce byly tři zcela odlišné různými zákony chráněné hodnoty: ochrana vodního toku, regulace odpadového hospodářství, ochrana prrírody a krajiny (prrírodní rezervace). Dle NSS šlo proto o tři různé skutky. NSS v tomto polemizoval právě s rozhodnutím Zolotukhin. Jak totiž NSS uvedl, nepřehlédl, že velký senát ESLP v rozsudku Zolotukhin proti Rusku při posuzování zásady ne bis in idem odmítl přístup kladoucí důraz na právní kvalifikaci deliktu. Přesto byl NSS toho názoru, že „za rozhodný komparátor pro stanovení prvku idem je nutno považovat skutek de iure" (bod 30). NSS v tomto poukázal též na specifika systému správního trestání. K řízení o jednotlivých správních deliktech jsou totiž mnohdy věcně př́slušné různé správní orgány. Shodným jednáním pachatele tak může dojít k vyvolání různých právních následků (a k porušení či ohrožení zcela odlišných zájmů a hodnot), a tedy ke spáchání správních deliktů stanovených různými právními předpisy a sankcionovaných různými správními orgány. $\mathrm{V}$ takových př́padech je to právě konstrukce skutku de iure, která umožňuje postižení pachatele za všechny právně relevantní následky jeho jednání. ${ }^{18}$

Právě uvedený př́klad ukazuje, že pojetí ne bis in idem, které zaujal ESLP v kauze Zolotukhin, je ve velkém napětí s pojetím správního trestání v České republice. ${ }^{19}$ Protože přehodnocení skutku de facto ze strany ESLP není reálné, je třeba přehodnotit judikaturu NSS, ostatně již jen proto, že další vývoj judikatury ESLP oslabil osten kritiky, který v lednu 2012 zazněl z NSS. Správní trestání právnických osob a podnikajících fyzických osob by nemělo být nadále sektorově rozděleno. Různé správní orgány jednající v rámci různých zákonů by o sobě navzájem měly vědět, jednotlivá řízení by měla být bud’ spojena v jedno, nebo alespoň koordinována. Právě to přitom judikatura ESLP požaduje (viz dále analyzovaná kauza $A$ a $B$ proti Norsku). Nezakazuje totiž v různých ř́zeních zohlednit rozdílné zákonem chráněné zájmy. Přikazuje však, aby tato rozdílná řízení byla vzájemně sladěna (viz dále). Tím padá i základní argument, který proti rozhodnutí Zolotukhin vznesl v kauze obce Kralice nad Oslavou Nejvyšší správní soud.

18 NSS si byl samozřejmě vědom, že roztřrištěnost úpravy skutkových podstat jednotlivých správních deliktů může někdy vést k částečnému překrývání se těchto skutkových podstat. „Avšak jsou to právě tyto prípady, kdy je na mistě chránit pachatele protiprávní ćinnosti proti dvojímu trestáni aplikací aásady ne bis in idem. " $\mathrm{K}$ tomu, aby bylo možné postihnout pachatele na základě totožného jednání za dva různé delikty, nestačí samotná existence dvou nominálně odlišných skutkových podstat deliktu. Teprve „odlišnost v právně významném následku jednáni" zakládá existenci dvou samostatných skutků, o nichž je možné vést samostatná řízení (bod 34).

19 Problémy ale vyvstávají i mimo oblast správního práva. Slavným př́íkladem problematických dopadů kauzy Zolotukbin v judikatuře je třebas rozhodnutí kárného senátu Nejvyššího soudu ze dne 30. 10. 2008, sp. zn. 1 SKNO 10/2008, kterým bylo potvrzeno zastavení kárného řízení proti soudci Z. Sovákovi s ohledem na to, že byl za tentýž skutek (porušování autorského práva) postižen v trestním řízení. Nijak nebylo zohledněno to, že kárné řízení proti soudci vycházelo z naprosto odlišných právem chráněných hodnot, totiž z toho, že soudce „vykradením“ cizího autorského díla a jeho prezentování jako svého zásadně zpochybňuje soudcovský slib a zpochybňuje postavení justice ve společnosti. 
Právě nastíněný problém koordinace různých trestních (v širokém slova smyslu) řízení nedávno vygradoval v českém právu v souvislosti se vztahem daňového penále a trestní sankce za zkrácení daně. Česká judikatura se tomuto problému do nedávna vyhýbala s tím, že na daňové penále nenazírala jako na trestní obvinění ve smyslu čl. 6 odst. 1 Úmluvy. ${ }^{20}$ Rozšířený senát NSS však v listopadu 2015 ve věci Odeř Agrar ${ }^{21}$ vyslovil názor, že daňové penále dle \251 daňového řádu má povahu trestu. Rozšířený senát zde vyšel z judikatury ESLP, kterou v podstatě bez dalšího aplikoval. Rozšřřený senát se otázce zákazu dvojího trestání za stejný skutek nevěnoval (podstatou sporu před NSS byla jen otázka, zda je daňové penále trest ve smyslu čl. 6 odst. 1 Úmluvy a zda proto je třeba aplikovat právní úpravu pro delikventa příznivější, jakkoliv časově pozdějšíi).

Význam tohoto problému ukazuje i to, že jej v listopadu 2016 řešil též velký senát ESLP.22 Dospěl k závěru, že ,je legitimni, aby si státy mobly vybrat vzájemně se doplňujici právni odpovédi na společensky neprijatelné jednáni (napríklad nedodrơováni pravidel silničního provozu ci krácení dani) pomoci ruizných rízeni, k.terá tvorí souvislý celek, scilem uchopit rüzné aspek.ty danébo společenskébo problému za predpokladu, že kumulace téchto právnich odpovédi neprédstavije pro dotčeného jednotlivce nadmèrnou zátěž “23 resp. aby využily „uceleného“ přístupu k danému společensky škodlivému jednání, zejména jeho postihem v rámci souběžných řízení vedených různými orgány za různým účelem. ${ }^{24}$ Dvojí stíhání však nesmí jít k tíži jednotlivce, ale mělo by být výsledkem uceleného systému umožňujícího odpovědět na rưzné aspekty provinění „prédvídatelným a priměreným zpiosobem, který vytvárí souvislý celek, tak:že dotyčný jedinec neni vystaven nespravedlnosti“ 25 Otázka, kdy přesně jedno řízení pravomocně skončí, resp. v jakém pořadí jsou rrízení vedena, proto není sama o sobě podstatná. ${ }^{26}$

ESLP zdůraznil test „dostatečně úzkée věcné a časové spojitosti“, z něhož plyne, že musí být kumulativně dána spojitost věcnái časová dvojího trestního stíhání. ${ }^{27}$ Sledované účely i použité prostředky se musejí vzájemně věcně doplňovat a být spojeny $v$ čase, možné důsledky

20 Jak uvedl již rozsudek NSS ze dne 28. 4. 2011, čj. 1 Afs 1/2011-82, daňové penále (zde podle \ 63 zákona č. 337/1992 Sb., o správě daní a poplatků) „nepochybně zasabuje do majetkové sféry daňovébo dlužníka, nicméně s obledem na jeho základni funkci (paušalizovaná nábrada eventuálni škody, jež by státu mobla vz̧niknout zpoždèním daňových prójmui) je nelze chápatjako správni delike či trestni obvinèni ve smyslu čl. 6 odst. 1 Úmluvy o ochrané lidských práv a základnich svobod (c. 209/1992 Sb.)" (obdobně třebas rozsudky NSS ze dne 2. 12. 2011, čj. 2 Afs 13/2011-73, a ze dne 7. 8. 2014, čj. 10 As 48/2014-35, bod 19).

21 Usnesení rozšířeného senátu NSS ze dne 24. 11. 2015, čj. 4 Afs 210/2014-57, č. 3348/2016 Sb. NSS, Oder Agrar.

22 Rozsudek velkého senátu ze dne 16. 11. 2016, A a B proti Norsku, č. 24130/11. Pro českou vnitrostátní reflexi tohoto rozsudku srov. usnesení velkého senátu trestního kolegia NS ze dne 4. 1. 2017, sp. zn. 15 Tdo 832/2016, č. 15/2017 Sb. rozh. tr. Pro konkrétní aplikaci pak srov. body 75 až 90 usnesení.

23 A a B proti Norsku, \121.

24 Ibid., $\int 123$.

25 Ibid., $\int 122$.

26 Ibid., \ 126-128. Srov. též rozsudek ze dne 18. 5. 2017, Jóhannesson a ostatni proti Islandu, č. 22007/11, \48.

27 A a B proti Norsku, \125. 
takové organizace právního řešení daného jednání musejí být ve vztahu k dotčenému jednotlivci přiměřené a předvídatelné. ${ }^{28}$

ESLP byl poněkud strohý při analýze časové souvislosti dvojího stíhání. Časová spojitost obou řízení totiž neznamená, že obě řízení musí být od začátku do konce vedena současně. Časová souvislost však musí být dostatečně těsná, aby jednotlivce chránila před nejistotou, zdlouhavostí a průtahy v řízení.

$\mathrm{Na}$ rozdíl od poměrně strohého vypořádání se s časovou spojitostí byl ESLP mnohem detailnější u vysvětlení spojitosti věcné. Přitom poskytl též prríklady faktorů rozhodných pro určení, zda mezi dvěma řízeními existuje dostatečně úzká věcná spojitost. Bude tak podstatné:

- zda obě samostatná ř́izení sledují vzájemně se doplňující cíle, a tedy zda se týkají, nikoli pouze in abstracto, ale také in concreto, různých aspektů daného protispolečenského jednání;

- zda je kombinace daných řízení předvídatelným důsledkem téhož postihovaného jednání, a to v právu i v praxi;

- zda jsou př́slušná řízení vedena takovým způsobem, kterým se v maximální možné míre zabrání opakování při shromažd’ování a hodnocení důkazů, zejména skrze odpovídající vzájemnou součinnost mezi jednotlivými příslušnými orgány, díky které se prokázané skutkové okolnosti využijí i v druhém řízení;

- a především, zda je sankce uložená v řízení, které bylo skončeno jako první, zohledněna $\mathrm{v}$ řízení, které je skončeno jako poslední, s cílem zamezit, aby byl dotčený jednotlivec $\mathrm{v}$ konečném důsledku vystaven nadměrné zátěži, přičemž pravděpodobnost posledně zmiňovaného rizika je nejnižší, pokud existuje mechanismus započtení, kterým se zajistí přiměřenost celkové výše všech uložených sankcí (\132).

ESLP právě uvedenými kritérii vlastně ex post a poměrně dost komplikovaně napravuje škodu spáchanou předchozím striktním vymezením totožnosti skutku de facto $\mathrm{v}$ kauze Zolotukhin. ${ }^{29}$ Všimněme si totiž, že jakkoliv rozdílné právem chráněné hodnoty nemajî význam pro určení totožnosti skutku (idem), podrží si význam pro akceptovatelnost dvojího řízení o tomtéž skutku (bis). ESLP tak vlastně přesunul problém aplikace zákazu ne bis in idem ze skutku (idem) do opakovaného řízení (bis). O jasnosti a předvídatelnosti nového postoje ESLP mám však hluboké pochyby.

ESLP zde navázal i na svou dosavadní judikaturu, která rozlišuje tradiční trestní věci, na straně jedné („turdé jádro trestního práva“), a věci, které striktně vzato nepatři do tradičních kategorií trestního práva, například správní sankce, vězeňská kárná řízení, celnî právo, právo hospodářské soutěže atd. Existují proto „obvinění z trestného činu“

28 A a B proti Norsku, \130.

29 Disentující soudce v kauze $A$ a B proti Norsku de Albuquerque má za to, že ESLP nám novým rozhodnutím bere zpět hlavní výdobytky rozhodnutí Zolotukhin. 
(ve smyslu čl. 6 odst. 1 Úmluvy) různé závažnosti. ${ }^{30}$ Skutečnost, že jedno z obvinění se vztahuje k oblasti mimo „turdé jádro trestního práva“ (což budou pravidelně i př́ípady českého přestupkového práva), je tak dodatečným faktorem pro závěr, že kombinace řízení (asi) nebude znamenat nepřiměřenou zátěž pro obviněnou osobu. ${ }^{31}$ Nutno nicméně upozornit, že pouhá skutečnost, že jde o obvinění mimo oblast „tvrdého jádra trestního práva“, sama o sobě (bez přistoupení dalších zde analyzovaných podmínek) dvojí trestání rozhodně neospravedlní.

V praxi tak bylo jako porušení zásady ne bis in idem shledáno samostatné trestní stíhání a samostatné daňové řízení, která ve svém celku probíhala přes devět let, byt' současně probíhala jen o něco málo než jeden rok. Navíc ESLP upozornil na převážně nezávislé shromažd'ování a posuzování důkazů. Proto v dané věci nebyla dostatečná časová a věcná spojitost mezi oběma řízeními, což vedlo k porušení čl. 4 Protokolu č. 7 Úmluvy. ${ }^{32}$

Lze tedy shrnout, že ESLP v roce 2016 potvrdil chápání totožnosti skutku (idem) jako de facto, tedy souhrnu faktů bez ohledu na právem chráněné hodnoty. Vzápětí však musel životaschopnost této dogmatické koncepce ,zachraňovat“ přihlédnutím k právem chráněným hodnotám při legitimizaci souběžného řízení o tomtéž skutku. Nakonec se tedy dá říci, že by měl být ve věci Kralice „revoltující“ NSS uspokojen. K další revoltě proti ESLP již v této věci není důvod. Dodávám, že je v podstatě s podivem, že celou záležitost ještě před rozhodnutím ESLP v kauze $A$ a B proti Norsku neukončil Ústavní soud. Zdá se totiž, že žádný stěžovatel nevyužil možnosti překonat rebelující NSS relativně jednoduchou cestou ústavní stížnosti. Což mimochodem naznačuje poměrně nízkou míru povědomí advokátů o judikatuře ESLP.

Naproti tomu nedávný rozsudek ve věci práv transsexuálư ${ }^{33}$ má zcela jiné konotace, čehož si Jan Petrov velmi dobře všímá. Nejde již o nějaká technická pravidla určování ne bis in idem, ale je to část nové „kulturní války“ ve vztahu k tzv. právům LGBTQ, která propuká na evropském kontinentu. Protože však v posledku šlo o neústavnost zákona, nejdůležitějším aktérem této „války“ bude nakonec Ústavní soud. Ten již kauzu protiústavnosti sporných norem hned několika zákonů projednává (Pl. ÚS 2/20).

30 Rozsudek velkého senátu ESLP ze dne 23. 11. 2006, Jussila proti Finsku, č. 73053/01, J 43; shodně A a B proti Norsku, \133; Pravdu má nicméně disentující soudce de Albuquerque v posléze uvedené kauze, podle něhož ,[n] aneštěstí Soud ani ve věci Jussila, ani poté nevynalo žil žádnou snabu, aby rozvinul souvislý prístup ke magna quaestio délici linie mezi ,turdým jádrem trestního práva' a zbytkem trestního práva [...] ", aby vysvětlil, jaké odlišné dopady v praxi z hlediska lidskoprávní ochrany budou vyplývat atp.

31 A a B proti Norsku, \133.

32 Srov. též rozsudek ze dne 18. 5. 2017, Jóhannesson a ostatni proti Islandu, č. 22007/11, \55.

33 Rozsudek ze dne 30. 5. 2019, čj. 2 As 199/2018-37. 


\section{Slovo závěrem}

Stat' Jana Petrova je jistě velmi kvalitní analýzou využití judikatury ESLP na NSS. Stálo by jistě za to podívat se, jak judikaturu ESLP využívají též správní soudci na krajských soudech, nebot' tam $\mathrm{v}$ poslední době přicházejí mladí vynikající právníci, od nichž se jistě můžeme dočkat brzy mnoha překvapení a inovativních právních názorů. $V$ každém případě mi bylo potěšením si Petrovovu práci přečíst a třemi poznámkami na ni reagovat. 